\title{
Mud Volcano: Revealing the Stratigraphy of Kendeng Basin, Indonesia
}

\author{
Ardian Novianto ${ }^{1,2}{ }^{*}$, Sutanto$^{1}$, Suharsono ${ }^{2}$, Carolus Prasetyadi1, Wahyu Hidayat ${ }^{2}$ \\ ${ }^{1}$ Geological Engineering Department, UPN “Veteran” Yogyakarta, Indonesia \\ ${ }^{2}$ Geophysics Engineering Department, UPN "Veteran” Yogyakarta, Indonesia \\ Email: *ardian.novianto@upnyk.ac.id
}

How to cite this paper: Novianto, A., Sutanto, Suharsono, Prasetyadi, C. and Hidayat, W. (2022) Mud Volcano: Revealing the Stratigraphy of Kendeng Basin, Indonesia. Open Journal of Yangtze Gas and Oil, 7, 48-64. https://doi.org/10.4236/ojogas.2022.71004

Received: September 9, 2021

Accepted: January 3, 2022

Published: January 6, 2022

Copyright $\odot 2022$ by author(s) and Scientific Research Publishing Inc. This work is licensed under the Creative Commons Attribution International License (CC BY 4.0).

http://creativecommons.org/licenses/by/4.0/ (c) (i) Open Access

\begin{abstract}
The Kendeng Basin, the major depocenter of the East Java Basin, has been filled with deep-sea clastic volcanic deposits since the Middle Tertiary, which developed into volcanic deposits in the Quaternary. With thick Quaternary volcanic deposits covering almost the entire basin, outcrops are only found in the north, forming a fold-thrust belt structure. The oldest known stratigraphic unit is the early Miocene Pelang Formation, which was deposited in the lower to the upper bathyal zone. Rocks older than the Pelang Formation have not been identified in this basin either from outcrops or drill-hole data. However, the geochemical analysis of oil seepage proves to be different because the oil source rock in Kendeng Basin was interpreted to be of older lithology than the Pelang Formation, indicating a potentially older stratigraphic unit in the Kendeng Basin that has not been revealed to date. Mud volcanoes transported rock material from the Kendeng Basin to the surface, uncovering the stratigraphy that has been an enigma. The material in question includes Nummulites limestones, conglomerates, and quartz sandstones. Paleontological analysis results on rock fragments indicate that they belong to the Middle Eocene age, so they are older than the Pelang Formation. Mud volcano also carried younger limestones to the surface identified as Miocene Age (equivalent with the Pelang Formation), which were deposited in a middle neritic environment, so they provided information that shallow areas possibly formed a horst-graben structure during the Miocene in the Kendeng Basin. The appearance of Eocene and Miocene rock fragments can be used to complement the stratigraphy and it also provides a potentially new concept of sourcereservoir rock in the Kendeng Basin.
\end{abstract}

\section{Keywords}

Mud Volcano, Stratigraphy of Kendeng Basin, Eosen Sediment

\section{Introduction}

The central East Java Basin, or known as the Kendeng Basin, spans in a west-east 
direction in eastern Java Island, Indonesia, and has been interpreted to extend further northeast to the north of Bali Island. This basin is approximately $100 \mathrm{~km}$ wide and more than $400 \mathrm{~km}$ long. It is associated with a large region of negative Bouguer gravity anomalies (around $-50 \mathrm{mGal}$ ), which is strikingly different from its surroundings [1] [2] (Figure 1). The anomalies are interpreted as a deep basin (more than $6 \mathrm{~km}$ deep) filled with a thick sequence of turbidite volcaniclastic sandstones and pelagic mudstones sediments [1] [2]. Current geological conditions show a small part of the northern Kendeng Basin exposed to the surface, forming a fold-thrust belt system. Meanwhile, the southern geology that is mainly covered by Quaternary volcanic deposits remains unknown. The oldest known stratigraphic unit is apparent from the outcrops in the southern Juwangi, Purwodadi (Central Java), which consist of tuffaceous mudstones rich in globigerina of the Oligocene to the Early Miocene, part of the Pelang Formation [2]. There is not much information on any stratigraphy older than this formation due to the absence of outcrops and drilled wells.

Geologically, a mud volcano is often associated with young magmatic activities, intensive tectonic compression and rapid sedimentation as the main factors of its formation [3] [4] [5]. Mud volcanoes occur when excessive pressure makes fluidized sediments penetrate upward as a result of buoyancy forces and differential pressure and migrate along with a fault structure. In its development, the Kendeng Basin is compressed by subduction in the south, forming folds and thrust belts in the middle of Java Island. Sediments are substantially and quickly deposited into the basin, especially during the Mio-Pliocene to Pleistocene, and are

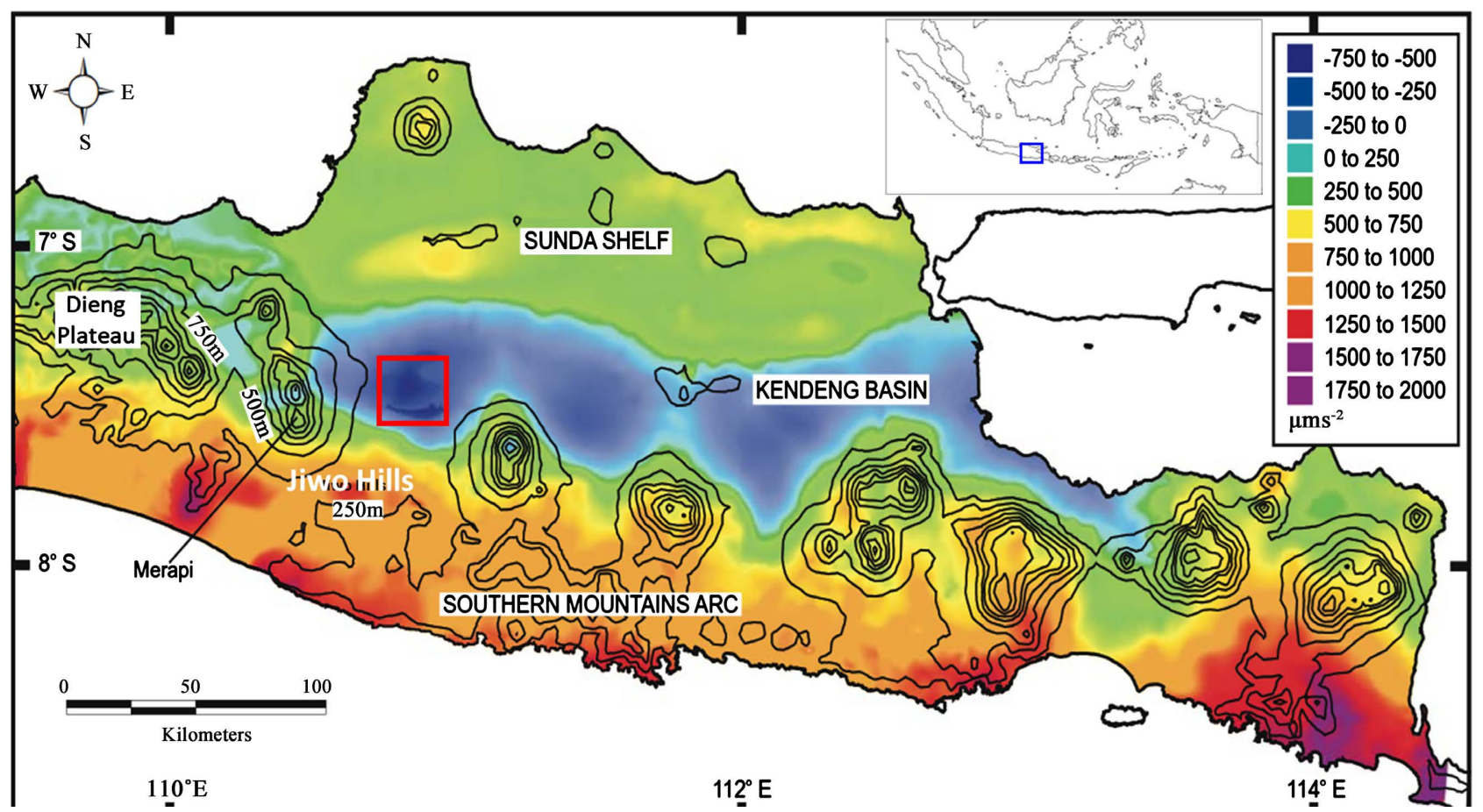

Figure 1. Map of Bouguer anomalies in eastern Java showing the position of the Kendeng Basin and the surrounding basins. The red box marks the location of the Boyolali Mud Volcano Complex, Indonesia [2]. 
directly suppressed by plate convergence from the south. These processes lead to an elisional system [3] that excessively pressurizes the basin into producing mud volcanoes/mud diapirs in several places. Some examples of these mud volcanoes are found in Central Java: Bledug Kuwu, Bledug Kesongo, and Bledug Kropak (south of Purwodadi), the mud Diapir and mud Volcano complex, and the Boyolali/Sangiran Dome; in East Java: Jari Mud Volcano (Nganjuk), LUSI (mud volcano eruptions), Porong, Kalang Anyar, Pulungan (Sidoarjo), and Gunung Anyar (Surabaya); in Madura: Socah (Bangkalan) (Figure 2).

The Boyolali Mud Volcano Complex is a cluster of ancient mud volcanoes that are no longer active. It has a west-east orientation and spans from Lake Ceklik (north of Solo) in the south to Sangiran Dome in the north. There are several outcrops of mud volcanoes in the complex, namely in Jatikuwung, Lake Tengklik, Gununglondo, and Sangiran in Boyolali Regency [6] [7], in the forms of diapirs, mud balls, sills-like volcanic deposits, and hardened mud volcanoes (Figure 3 ). These features are geologically fascinating because they are formed at the boundary of the folding and faulting zones in the middle of the Kendeng Basin. Furthermore, the mud volcano complex brought several metamorphic basement blocks, limestone blocks, and conglomerates identical to the ones outcrop in other basins, especially Nanggulan, Karangsambung, and Jiwo-Bayat Hills [8] [9]. This paper will discuss the possibility of an older stratigraphy beneath the Pelang

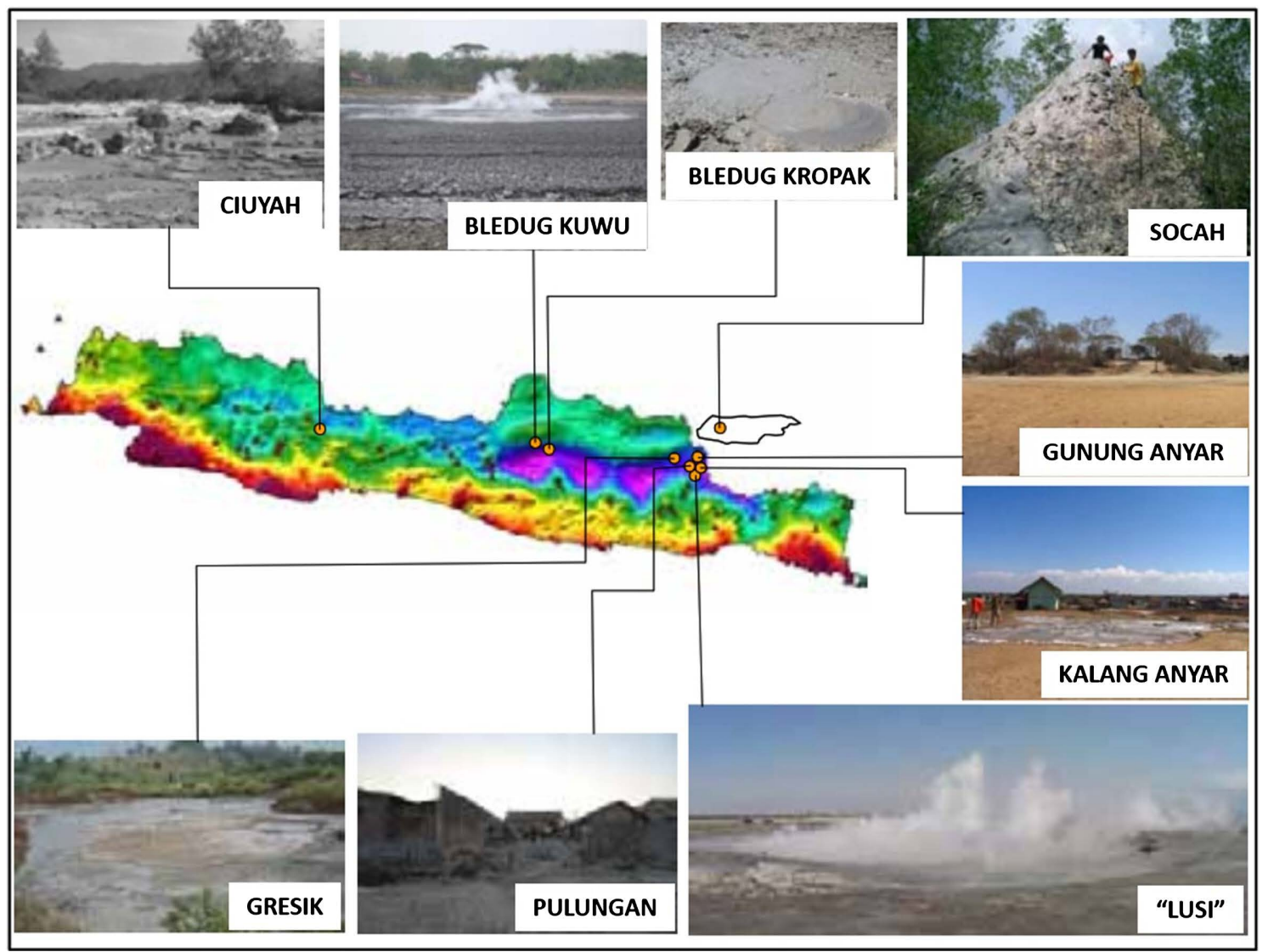

Figure 2. Mud volcano distribution and surface expression in Kendeng Basin from Java to Madura Island [3]. 

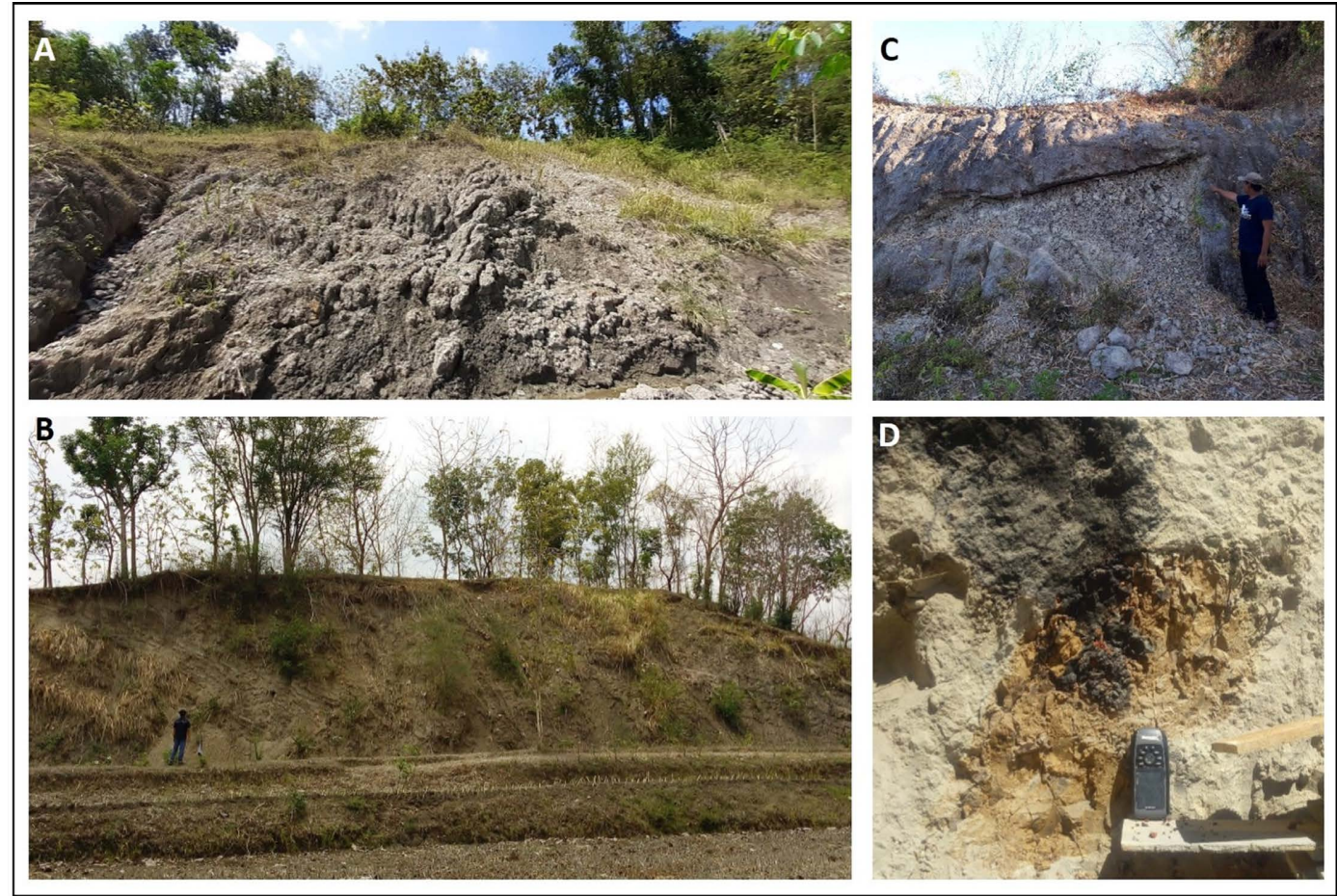

Figure 3. The appearances of ancient mud volcanoes in the Boyolali Mud Volcano Complex, in the form of diapers in Sangiran ((A), (B)), intercalations in volcanic deposits (sills-like) in the Jatikuwung area (C), mud balls at Lake Tengklik (D).

Formation based on paleontological analysis of the materials carried by the mud volcanoes and its effect on the concept of source-reservoir rock in the Kendeng Basin.

\section{Stratigraphy of the Kendeng Basin}

Gravity anomalies show that the Kendeng Basin is an asymmetric depression pattern sloping to the south, with its deepest region directly behind the arc. The basin is mainly filled with volcanic deposits from the southern mountains, which are composed of interbedded volcaniclastic sandstones and pelagic mudstones. Sandstones dominate the southern edge of the basin and become finer in size towards the north. These mudstones still contain volcanic elements even though they were deposited in a deeper basin. This basin is interpreted to start taking form simultaneously with the volcanic arc activities, and its history of subsidence is closely related to this volcanic activity [10]. The northern side of the basin, which is the edge of Sundaland, is relatively shallower.

The stratigraphy of the Kendeng Basin can be seen from the outcrops, especially on the northern side. It begins with deep-sea sediments formed mainly by turbidite systems, followed by shallow marine sediments in the middle, and it ends with non-marine deposits. In addition, the stratigraphy can be divided into seven formations (Figure 4), from the oldest to the youngest: Pelang, Kerek, Kalibeng, Sonde, Pucangan, Kabuh, and Notopuro. Pelang Formation, the oldest known formation in the Kendeng Basin, is slightly exposed at the surface in 


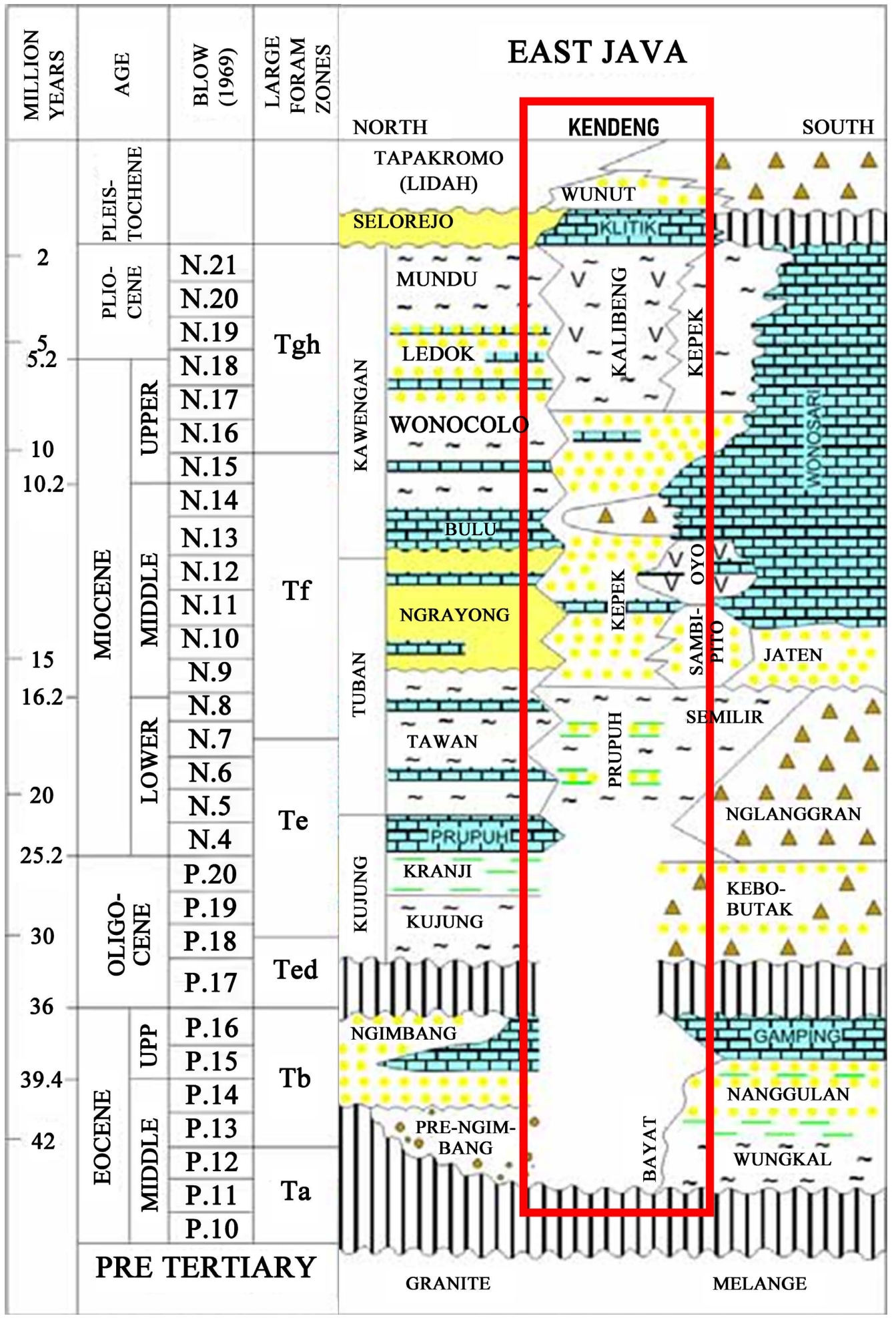

Figure 4. The Stratigraphic Column Composite of East Java Basins, showing the stratigraphic relationship between the basins. Unlike the surrounding basins, the Eocene-Miocene stratigraphy of the Kendeng Basin has not been defined [3].

Juwangi, south of Purwodadi (Central Java), as a result of the thrust fault. The constituent lithology is marl with limestone lenses containing foraminifera. The 
base of this formation is unknown, but paleontological analysis of the content, planktonic foraminifera, shows N3-N9 (Late Oligocene to Middle Miocene). Based on the analysis of the benthonic foraminifera, it is known that Pelang Formation, which was deposited in the lower to the upper bathyal zone. Kerek Formation is above the Pelang Formation with a fault contact as the boundary. It has a characteristic alternation of clay, marl, calcareous-tuffaceous sandstone, and tuffaceous sandstone. This stratification often produces a typical sedimentary structure, viz. graded bedding that indicates the flysch sequence. The planktonic and benthonic foraminifera fossils indicate that the formation was formed in the Middle to Late Miocene (N10-N18) in a shelf environment. It can be divided into three members based on the location type, from oldest to youngest: Banyuurip, Sentul, and Kerek Limestone. 1) Banyuurip Member is composed of alternating marl, clay with calcareous tuff sandstone, and tuffaceous sandstone. Calcareous sandstones are found in the middle of the alternation, while sandy calcarenite layering with thin intercalation of fine tuff characterizes the top. This member is N10-N15 (middle to upper Middle Miocene); 2) Sentul Member comprises a similar alternation to Banyuurip Member but with a thickening tuff layer and is estimated to be N16 of age (lower Middle Miocene); 3) Kerek Limestone Member, the uppermost member, is composed of tuffaceous limestones alternating with clay and tuff layers. The age is N17 (middle Upper Miocene). Kalibeng Formation conformably lies above the Kerek Formation. It is generally composed of unbedded marl that is yellowish-white to bluish-grey and rich in planktonic foraminifera. Existing fauna associations indicate that the lower Kalibeng Formation was formed in N17-N21 (Late Miocene to Pliocene). At the base, several layers of sandstone were developed into debris-flow deposits known as the Banyak Member. Towards the east, the upper part of this formation has developed into marine volcanic deposits with a turbidite structure. This facies is referred to as Atasangin Member. Sonde Formation is composed of the Klitik Member at the base, i.e., well-bedded soft yellowish-white marly or sandy calcarenites containing planktonic and large foraminifera, followed by gravel-sized limestone fragments, sandy marl deposits, then bluish-green clay marl in the uppermost layer. Pucangan Formation in the western and central Kendeng Basin unconformity overlies the Sonde Formation. It is widely exposed in West Kendeng between Trinil and Ngawi, with a thickness ranging from 61 to $480 \mathrm{~m}$ and the age of Late Pliocene (N21) to Pleistocene (N22). It has developed into volcanic facies and black clay facies in the Sangiran area. Kabuh Formation, lying conformably above the Pucangan Formation, is braided-river deposits characterized by intensive crossbedded structures with intercalations of conglomerate and tuff. It consists of many gravel-sized fragments and sandstones with non-volcanic materials like quartz and contains fossils of freshwater mollusks and Middle Pleistocene vertebrates. According to Van Bemmelen (1972), the western Kendeng Zone (Sangiran area) begins with a conglomerate layer with andesite fragments, concreted limestones, and Globigerina limestones, followed by tuffaceous sandstone deposits with cross-bedded and bedded structures. Notopuro Formation lies unconformity above the Ka- 
buh Formation. Its lithology consists of lava breccias interspersed with tuffaceous sandstones and volcanic conglomerates. More intercalations of tuffaceous sandstones can be found in higher stratification. At the top, there are intercalations or lenses of volcanic breccias with gravel fragments consisting of andesite and pumice, which are characteristic of the Notopuro Formation. This formation is generally a lava deposit formed in a terrestrial environment in the Late Pleistocene, with more than $240 \mathrm{~m}$ in thickness.

The Pelang Formation is known as the oldest exposed rock in the Kendeng Basin, however, geochemical analysis shows indications of rocks older than the Pelang Formation. Geochemical analysis of oil seepage and source rock analysis of the Pelang formation did not show a good correlation. The TOC analysis of the Pelang Formation shows a low to good category with immature-early mature maturity with low ability of generating hydrocarbons from mixed kerogen type II and III. Geochemical data of oil seepage shows the opposite, with late mature Type III kerogen produced by algae in a lacustrine or open marin environment. This analysis concludes that the Pelang Formation is not a source rock of oil seepage that appears in the Kendeng Basin but comes from rocks that may be older than the Pelang Formation [11] [12] [13].

\section{Research Data}

This research was conducted by analyzing the relative age of rocks from the foraminifera fossils embedded in the rock fragments that mud volcanoes brought to the surface. The mud volcano carried some materials to the surface, including lumps or chunks of limestone containing large benthonic foraminifera-i.e., Nummulites, conglomerates, quartz sandstones, silt, hard clay fragments, limestones, and limestones with mollusk shell fragments. The rock fragments are interpreted as originating from the formation that composes the stratigraphy of the Kendeng Basin at a deeper position and is not exposed to the surface.

\section{Methodology Analysis}

The first analysis of rock fragments brought by the Mud Volcano is petrographic analysis. This analysis is visually to observe the rock fragments, matrix and mineral composition to separate the possible origin of the formation from the rock fragments. Based on this analysis, the rock fragments can be grouped into two groups, namely Nummulites limestones, conglomerates, sandstones, hard clay fragments, and silt as the first group, and the second group consists of limestones, limestones with mollusk shell fragments, clay, and tuffaceous sandstones.

The next process is a paleontological analysis in the laboratory. Paleontological analysis is based on analysis of microfossils contained in rocks, which are planktonic foraminifera and benthonic foraminifera. Planktonic foraminifera are used to determine the relative age of rock fragments by finding the early and late appearance of foraminifera contained in rock samples. Observations on the detailed morphology of the microfossils serve to determine the genus and species 
names based on the physical properties and optical appearance of the microfossils. Determination of relative age is used in compiling an unknown stratigraphy in the Kendeng Basin based on the age of the foraminifera in the rock fragments. Paleobatimetric analysis was performed to interpret the depth of the depositional environment based on the presence of benthonic foraminifera in rock samples.

\section{Result and Discussion}

The rock fragments carried by the mud volcano are grouped into two based on their possible relative age. Petrological (physical) analyses identified the first group as Eocene rocks and interpreted the second group as rocks of younger age. The descriptions of the two groups are as follows.

The first group (Eocene rocks) consists of Nummulites limestones, conglomerates, sandstones, hard clay fragments, and silt (Figure 5). Nummulites limestones are limestones composed of Nummulites, i.e., a large lenticular benthic foraminifera fossil characterized by its numerous coils and subdivided by septa into chambers. It is an index fossil typical of the Eocene to Miocene Epochs. Other identified lumps or chunks are conglomerates, sandstones, clay, and silt. The conglomerates found in the mud volcano area are composed of monatomic quartzite fragments that are about $0.2-0.5 \mathrm{~cm}$ in diameter. The presence of quartzite in conglomerate fragments indicates the breakdown of quartz-rich Basement. Sandstones show fine-sized grains containing abundant quartz minerals, while the clay forms thin sheets of hard fragments. Another rock is silt with a bioturbation structure resulting from organism activities at the time of deposition.

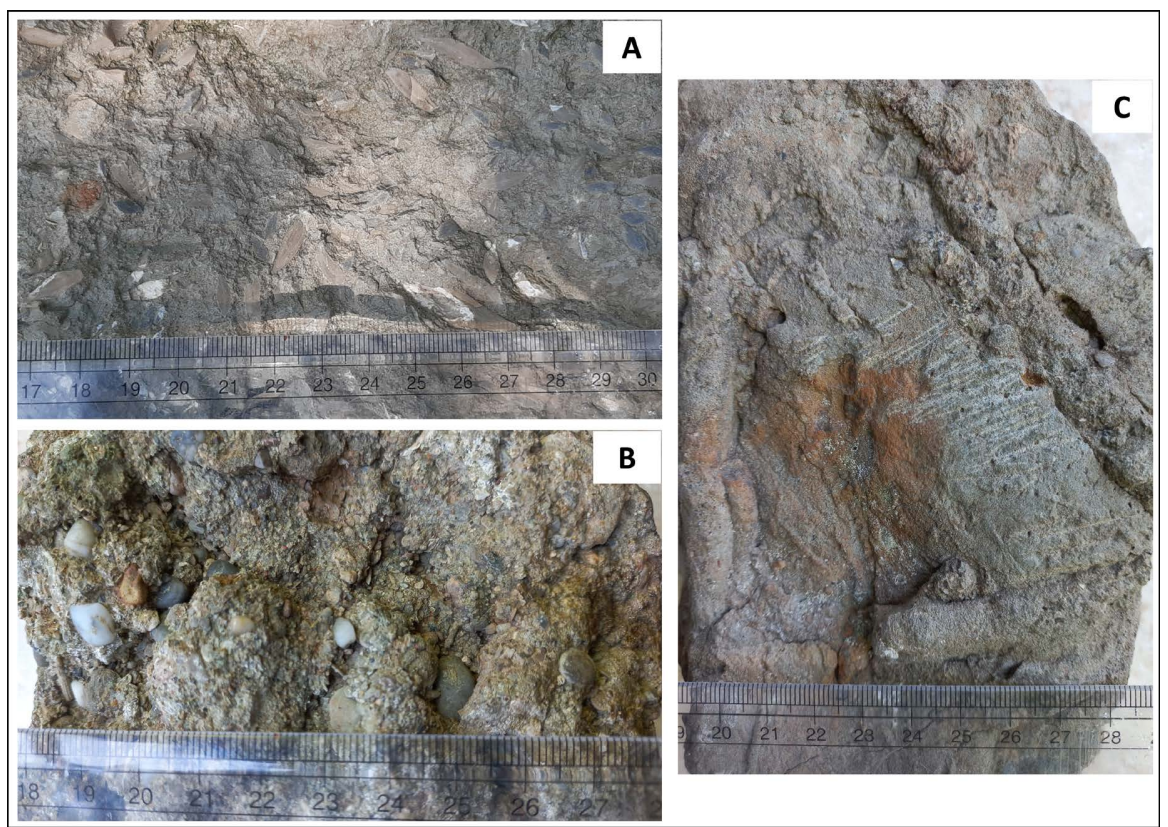

Figure 5. Group I, lumps of material carried by the mud volcanoes in the Boyolali Mud Volcano Complex, consisting of Nummulites limestones (A), conglomerates with quartzite fragments (B), and silt showing a bioturbation structure $(\mathrm{C})$. 
Based on grain size and bioturbation structure, it can be concluded that the rock was deposited in a shallow marine environment with calm currents.

The Nummulites limestone and conglomerate lumps found as fragments in the Boyolali Mud Volcano Complex are similar to the outcrops in the pretertiary Jiwo-Bayat Hill Complex located approximately $50 \mathrm{~km}$ southwest. The latter, known as one of the oldest outcrops on Java Island, comprises metamorphic rocks: phyllite, schist, and intercalations of marble and quartzite. These rocks are interpreted as the basement of the southern mountain range and the northern basin, including the Kendeng Basin. Paleogene sediments unconformably overlie the pretertiary complex. They are part of the Wungkal-Gamping Formation, which is composed of conglomerate, quartz sandstone, shale, and Nummulites limestone of the Eocene Epoch. This rock series is deposited in a shallow marine environment, from littoral to neritic zones. The characteristics of the basement and Paleogene clastic sediments indicate that the tectonic setting during the Paleogene was continental [14].

The second group consists of limestones, limestones with mollusk shell fragments, clay, and tuffaceous sandstones. It can be found in an abundant quantity around the mud volcano in the form of lumps or in situ outcrops, especially around the Sangiran mud volcano (Figure 6). Petrological analysis indicates that

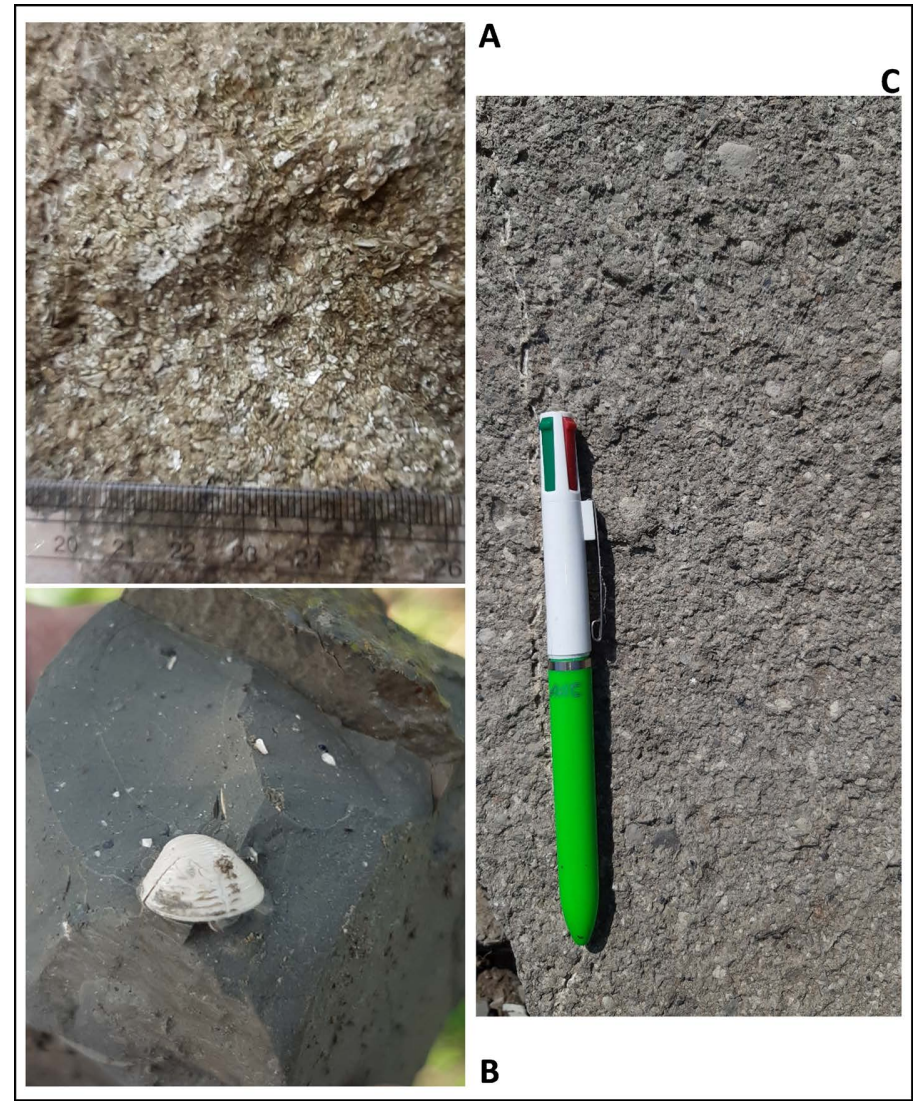

Figure 6. Group II, lumps of material around the Boyolali Mud Volcano Complex, comprising limestones, limestones with mollusk shell fragments (A), clay with mollusk brachiopod shells (B), and tuffaceous sandstones (C). 
this group is potentially younger than the first group, i.e., Neogene to Quaternary (including Pelang, Kerek, Kalibeng, Pucangan, and Kabuh Formations). Tuffaceous sand resulted from the developing volcanic activities in the Kendeng Basin and is commonly found in the Pucangan Formation. Large foraminifera shells also confirm the identified age, Quaternary, that is identical to the Kabuh Formation, during which the Pleistocene rocks of the Kendeng Basin developed into a fluvial system spanning to a delta at the foot of the volcanic cone.

Paleontological analysis of the matrix of the first group (Nummulites limestones, clay, and silt) found several foraminifera fossils. Some have been damaged or broken, probably due to tectonic activities during the Kendeng Basin formation or the mud volcano eruptions that brought them to the surface. Some of these foraminifera fossils are Morozovella aragonensis and Globigerinatheka mexicana barri, indicating Early to Late Eocene (Table 1). These Eocene index fossils prove that rocks older than the Pelang Formation (Late Oligocene to Middle Miocene) were also deposited in the Kendeng Basin. Therefore, the Early-Late Eocene rocks are interpreted as syn-rift sediments deposited in shallow marine environments, such as those in the Jiwo-Bayat Hill Complex or Nanggulan. This interpretation is based on the analysis of benthonic foraminifera, which revealed that the depositional environment was the middle to outer neritic zones (Table 2).

The paleogeographic reconstruction shows the possibility of faulting blocks in the Kendeng Basin around the Sangiran area that forms an east-west ridge or a series of islands where erosion occurs in several places and transgression and small reef formation in others [8]. Eocene sediments were deposited in low areas adjacent to these highs. Approaching the Plio-Pleistocene, a second tectonic activity occurred and activated the basement fault along the Kendeng Basin, especially in the west. Overpressure on the Early Miocene mud is concentrated at this fault, creating mud volcanoes transporting basement material and Eocene rocks to the surface (Figure 7).

For the second group, paleontological analysis of limestone and clay indicates Early Miocene or N5-N7, while the analysis of limestone with mollusk fragments shows N9 or Middle Miocene (Table 1). Paleobathymetric analysis of the benthonic foraminifera in limestones found that this rock was deposited in a middle neritic environment, while the clay analysis confirmed that the clay was deposited in a deeper environment, i.e., outer neritic zone. This bathymetric analysis supports the horst-graben pattern in the Kendeng Basin, which created the basis for the limestone formation during the Miocene or at the same age as the Pelang Formation. This horst-graben pattern is interpreted as a development of a pretertiary basement high with steep slopes in its north and south. The presence of this steeply sloping high can also be indicated by limestone deposits with shell fragments interpreted as turbidite deposits on steep slopes; also, the benthic foraminifera analysis revealed that the turbidite depositional environment was the edge bathyal zone (Table 2).

The presence of Miocene limestone that is stratigraphically equivalent to the 
Table 1. Relative age analysis based on planktonic foraminifera embedded in rock fragments carried by the mud volcanoes.

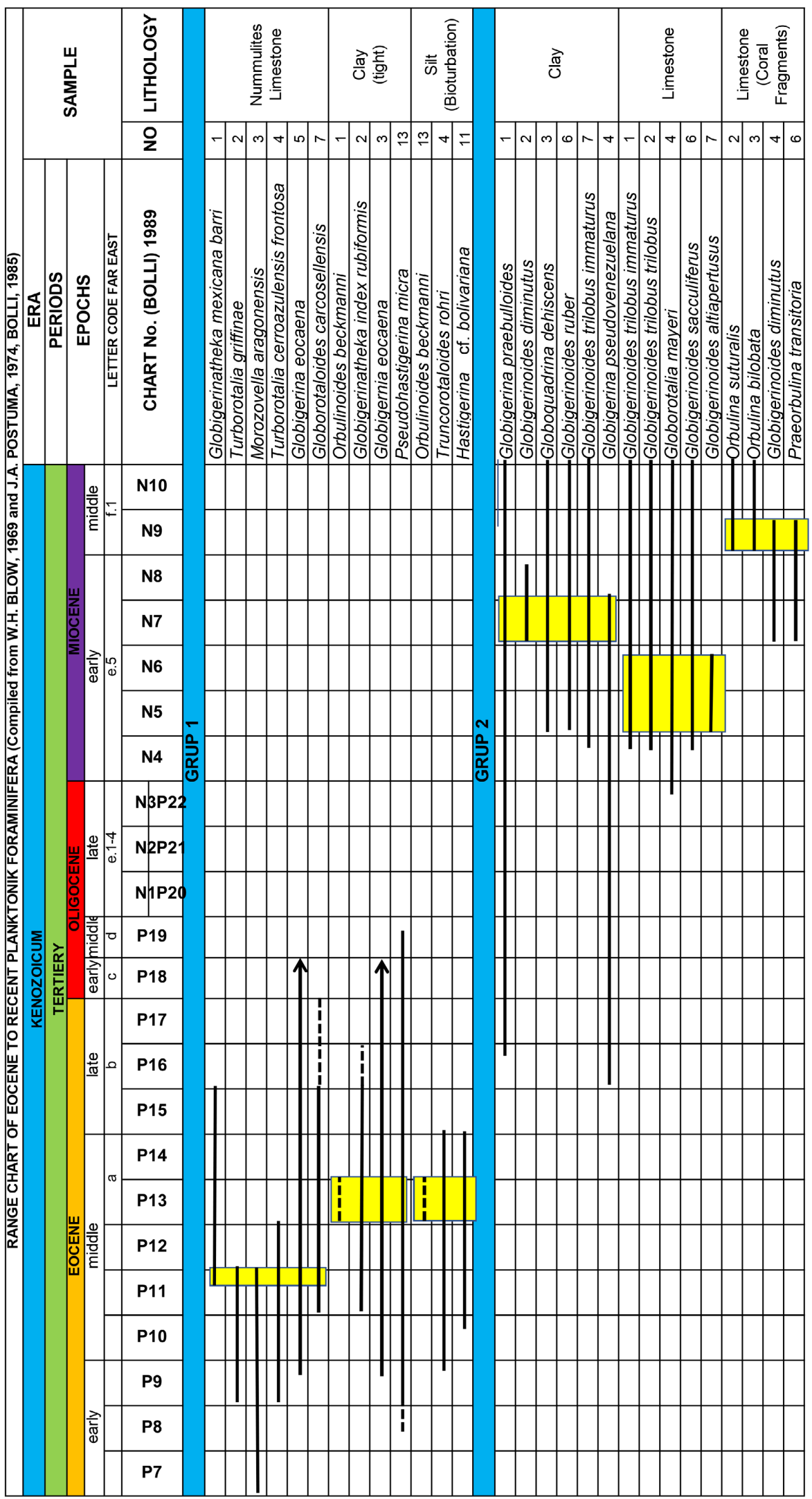


Table 2. Paleobathymetric analysis results based on planktonic foraminifera embedded in rock fragments carried by the mud volcanoes.

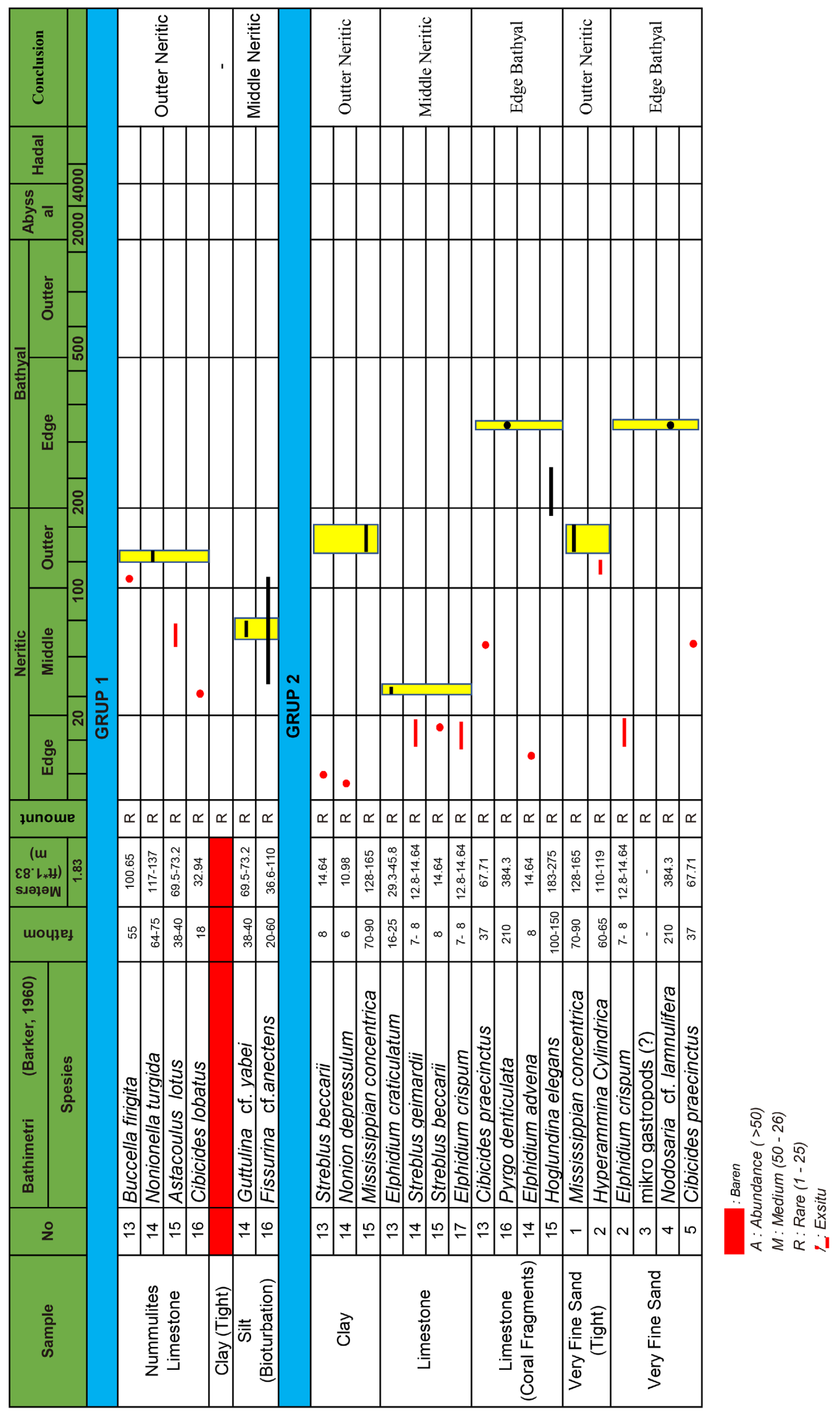




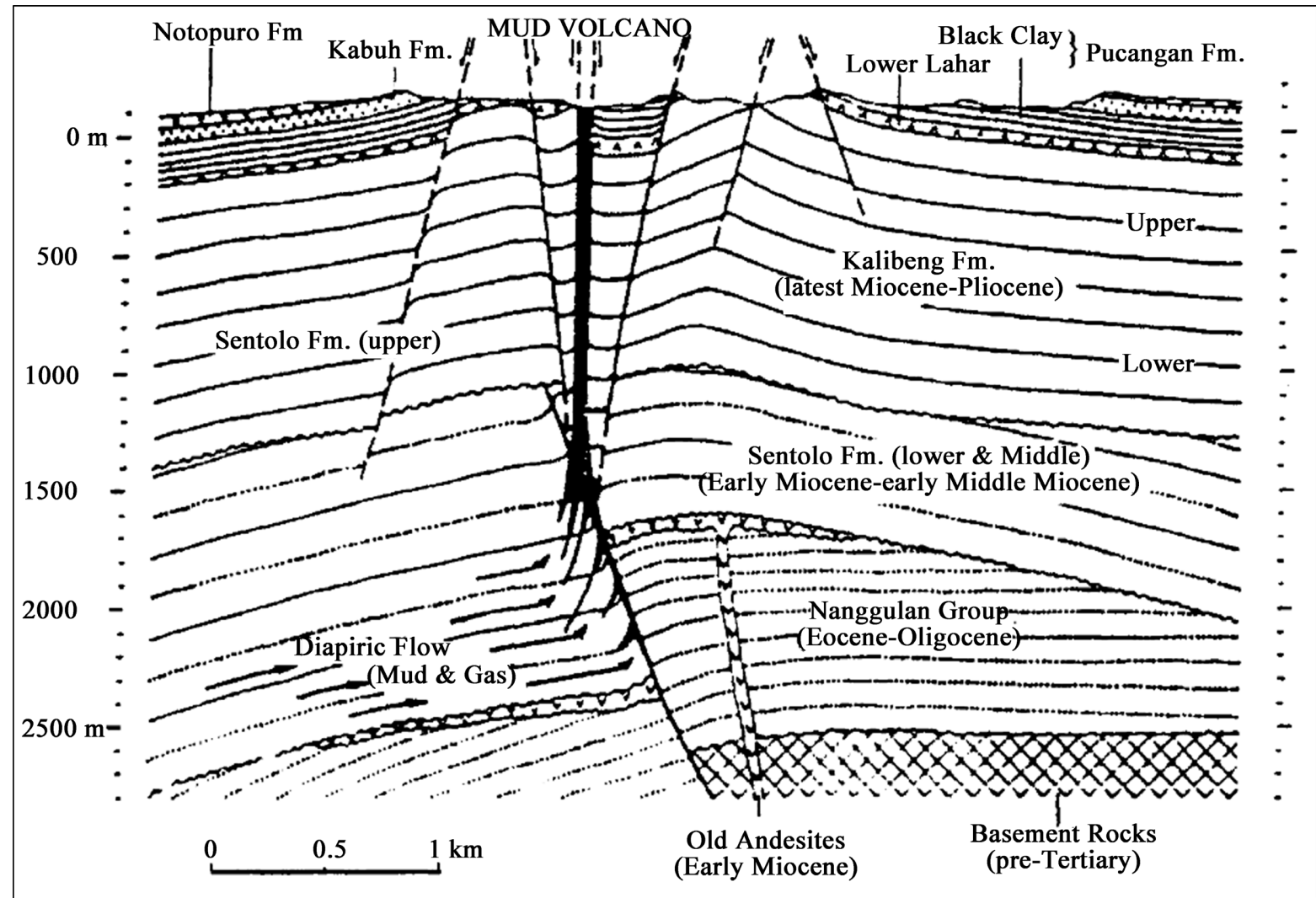

Figure 7. The Sangiran mud volcano model by Watanabe and Kadar (1985), showing the uplifting of the Eocene-Oligocene rocks of the Nanggulan group [8].

Pelang Formation is fascinating. It proves that a shallow region where carbonates grow might exist during the Miocene when the formation was generally deposited in a deep marine environment in the Kendeng Basin. Van Bemmelen (1972) has identified this Miocene limestone on a small hill in Mrisi at the northern foot of the Kendeng Basin, which contains Eulepidina and is known as Pelang Beds [9]. Although Mrisi Hill is no longer discoverable, it is interesting that its limestone can still be identified in the mud volcano fragments. The implication of this limestone for the petroleum system is the possibility of reservoir rock in the Pelang Formation, providing an additional target for hydrocarbon exploration in the Kendeng Basin.

The current research proves the existence of Eocene rocks that are older than the Pelang Formation and Miocene limestones in the Kendeng Basin. Also, the Eocene rocks have been found to share similarities with the ones composing the Gamping-Wungkal Formation in the pretertiary Jiwo-Bayat Hill Complex. Based on this evidence, the research suggests adding the rocks found in the fragments that the mud volcano transported to the surface to the Kendeng Basin's stratigraphy (Figure 8), especially with the Eocene rocks in the pretertiary Jiwo-Bayat Complex as reference. This finding also corroborates with the interpretation that the Eocene deposits are present as syn-rift deposits in a shallow marine environment or the neritic zone. This condition implies that the basement of 


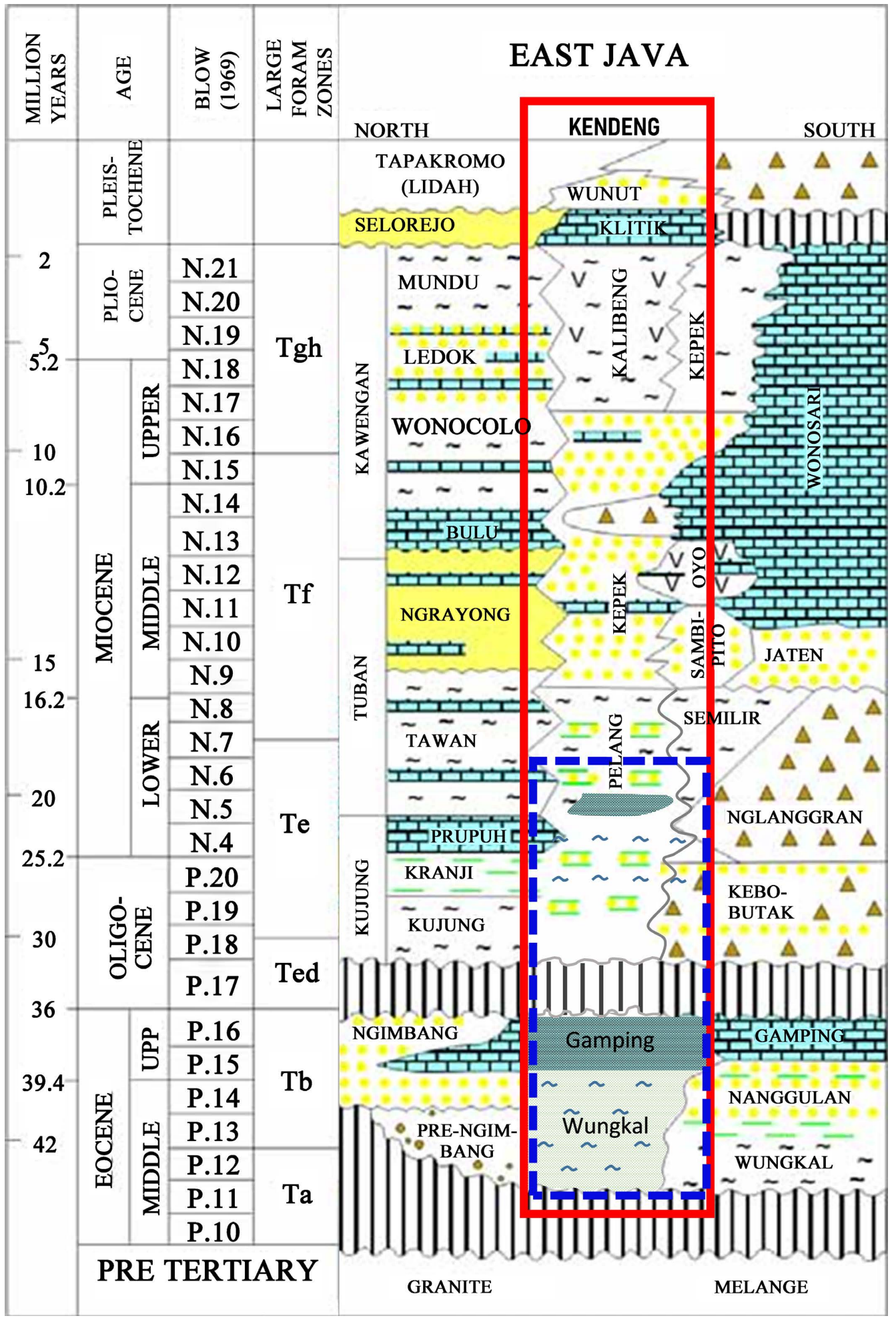

Figure 8. The proposed additional stratigraphic unit for the Kendeng Basin based on the analysis of rock fragments carried by the mud volcanoes in the Boyolali Mud Volcano Complex in the West Kendeng Basin (modified picture from Satyana 2008).

the Kendeng Basin is continental and is part of the Gondwana microcontinent. Other results from this study show the presence of Miocene limestones (equiva- 
lent to the Pelang Formation), indicating shallow marine depositional environments at the highs of the Kendeng Basin. With these Eocene rocks and Miocene limestones, it is highly likely that the Kendeng Basin has a source rock for hydrocarbons appearing as oil seepage, which simultaneously serves as a reservoir rock.

\section{Conclusions}

The Boyolali Mud Volcano Complex transported Eocene rocks from the Kendeng Basin's stratigraphy, namely limestones with large benthic foraminifera (i.e., Nummulites), conglomerates, and silted with a bioturbation structure. It also carried younger limestones to the surface, with some samples containing Mollusca shell fragments identified as Miocene Age (equivalent with the Pelang Formation). These Eocene rock fragments indicate that the Kendeng Basin also comprises rocks older than the Pelang Formation, of which the surface geological data is identified as the oldest known rocks in the basin. They also share similar characteristics with the Eocene outcrops in the pretertiary Jiwo-Bayat Hill Complex. Paleontological analysis results show that the benthic foraminifera indicate middle to outer Neritic zone as the depositional environments. Therefore, the tectonic setting of the Kendeng Basin during the Paleogene is interpreted as continental.

Miocene limestone fragments in this mud volcano provide information that shallow areas possibly formed a horst-graben structure during the Miocene in the Kendeng Basin. These fragments were deposited in a middle neritic environment. Other limestone fragments show Mollusca shell fragments, interpreted as turbidite deposits on the high slope. The analysis results of the benthic foraminifera in the rock samples indicate the edge bathyal zone.

The presence of these Eocene and Miocene rock fragments can be used to complement the stratigraphy of the Kendeng Basin. The study proves that the Eocene rocks exist in the Kendeng Basin, creating a potential source rock for oil and gas that has emerged as oil seepage at the surface, similar to the Eocene rocks in the Rembang Basin (oil and gas producer). Miocene limestones also provide a potentially new concept of reservoir rock in the Kendeng Basin.

\section{Acknowledgements}

The authors would like to thank the Head of the Paleontology Laboratory of the Universitas Pembangunan Nasional "Veteran" Yogyakarta for facilitating micropaleontological analysis. We also thank our colleagues, Dr. Umiyatun Ch., as a micropaleontologist for his support and discussion as well as to Ms. Idarwati, a Doctoral student from the Department of Geological Engineering, who has supported this research.

\section{Conflicts of Interest}

The authors declare no conflicts of interest regarding the publication of this paper. 


\section{References}

[1] Smyth, H., Hall, R., Hamilton, J. and Kinny, P. (2005) East Java: Cenozoic Basins, Volcanoes and Ancient Basement. Proceedings, Indonesian Petroleum Association, 251-266.

[2] Smyth, H.R., Hall, R. and Nichols, G.J. (2008) Cenozoic Volcanic Arc History of East Java, Indonesia: The Stratigraphic Record of Eruptions on an Active Continental Margin. In: Draut, A.E., Clift, P.D. and Scholl, D.W., Eds., Formation and Applications of the Sedimentary Record in Arc Collision Zones, 436, 199-222. https://doi.org/10.1130/2008.2436(10)

[3] Satyana, A.H. and Asnidar (2008) Mud Diapirs and Mud Volcanoes in Depressions of Java to Madura: Origins, Natures, and Implications to Petroleum System. Proceedings of Indonesian Petroleum Association, Thirty-Second Annual Convention \& Exhibition, 32, IPA08-G 139.

[4] Samankassou, E., Mazzini, A., Chiaradia, M., Spezzaferri, S., Moscariello, A. and Couto, D.D. (2017) Origin and Age of Carbonate Clasts from the Lusi Eruption, Java, Indonesia. Marine and Petroleum Geology, 90, 138-148.

https://doi.org/10.1016/j.marpetgeo.2017.11.012

[5] Mazzini, A. and Etiope, G. (2017) Mud Volcanism: An Updated Review. Earth-Science Reviews, 168, 81-112. https://doi.org/10.1016/j.earscirev.2017.03.001

[6] Bronto, S., Asmoro, P. and Efendi, M. (2017) Mud Volcanoes in Cengklik and Surrounding Area, Boyolali Districts Central Java Province. Journal of Geology and Mineral Resources, 18, 147-159. https://jgsm.geologi.esdm.go.id/index.php/JGSM/article/view/269

[7] Hidayat, W. and Novianto, A. (2020) Potential Analysis of Geological Disasters "Mud Volcano" at Boyolali and Its Surrounding Areas Based on Geomagnetic Methods. AIP Conference Proceedings, 2251, Article No. 040006. https://doi.org/10.1063/5.0016349

[8] Lunt, P., Netherwood, R. and Huffman, O.F. (1998) IPA Field Trip to Central Java. Indonesian Petroleum Association, Indonesia. https://archives.datapages.com/data/ipa/data/073/073001/1 ipa0730001.htm

[9] Lunt, P. (2013) The Sedimentary Geology of Java, Indonesia: Indonesian Petroleum Association. https://archives.datapages.com/data/ipa/data/073/073001/1 ipa0730001.htm

[10] Waltham, D., Hall, R., Smyth, H.R. and Ebinger, C.J. (2008) Basin Formation by Volcanic Arc Loading. In: Draut, A.E., Clift, P.D. and Scholl, D.W., Eds., Formation and Applications of the Sedimentary Record in Arc Collision Zones, 436, 11-26. https://doi.org/10.1130/2008.2436(02)

[11] Ramadhan, B., Maha, M., Hapsoro, S.E., Budiman, A. and Fardiansyah, I. (2015) Unravel Kendeng Petroleum System Enigma: Recent update from Transect Surface Observation of Kedungjati-Djuwangi-Ngawi Area, East Java. Proceedings Indonesian Petroleum Association, Thirty-Ninth Annual Convention \& Exhibition, 39, IPA15-SG-065.

[12] Pramono, W. and Amijaya, H. (2008) Karakteristik Geokimia Rembesan Minyak Bumi Di Daerah Bantal, Kecamatan Bancak, Semarang, Jawa Tengah "Geochemical Characteristic of Oil Seepage in Bantal Area, Semarang, Central Java”. Proceedings Indonesian Association of Geologists (IAGI), 37, 691-704.

http://repository.ugm.ac.id/digitasi/index.php?module=cari hasil full\&idbuku=3243

[13] Setyowati, T.P., Nusantara, Y.P., Wicaksono, A.B., Yusriani, A. and Hidayatullah, A. (2018) Characteristics of Oil Seepages Boyolali: Where Did They Come From? Proceedings Indonesian Society of Petroleum Geologists (ISPG), RF181SPG-020-SR, 
243-255. http://eprints.upnyk.ac.id/18955/1/img20190329 12163728.pdf

[14] Subroto, E.A., Noeradi, D., Priyono, A., Wahono, H.E., Hermanto, E., Praptisih and Santoso, K. (2007) The Paleogene Basin within the Kendeng Zone, Central Java Island, and Implications to Hydrocarbon Prospectivity. Proceedings of Indonesian Petroleum Association, Thirty-First Annual Convention \& Exhibition, 31, IPA07G-091. 